\title{
DETERMINANTS OF INCOME DIVERSIFICATION IN RURAL ETHIOPIA: EVIDENCE FROM PANEL DATA $^{8}$
}

\author{
Adugna Lemi ${ }^{9}$
}

\begin{abstract}
The aim of this study is to examine the determinants of income diversification in rural Ethiopia.

Rural households allocate their work time between farm and of-farm activities to have secure income (consumption) for their family members. However, it is not clear why some households participate only in farm activities while others engage in both. Using survey data collected from 1500 rural households in 1994 and 1997, this study investigates the impacts of demographic, economic, and risk factors on participation and intensity of off-farm activities. The results of the study show that families with high dependency ratio, female household heads, high livestock value, and poor quality of land participated less in off-farm activities. Competition between off-farm and farm activities and effects of seasonality were more apparent from the intensity results than from participation. Increased crop production and sale of part of production during the main harvest season led households to engage less in off-farm activities. The results also confirm that off-farm activities were practiced as a means of subsistence when crop production fails; otherwise farmers abandon off-farm activities.
\end{abstract}

JEL Classification: D1, J2

Key Words: Dynamic Livelihood, Off-farm Income, Diversification, Ethiopia

\section{Introduction}

Diversification of income sources, assets, and occupations is often common practice for individuals or households in different parts of the world, but for different reasons.

\footnotetext{
${ }^{8}$ The final version of this article was submitted in March 2009.

${ }^{9}$ Ph.D., Assistant Professor of Economics, Department of Economics, University of Massachusetts Boston, Boston, 02125, MA, USA. Email: Adugna.lemi@umb.edu

I would like to thank Catherine Lynde of the University of Massachusetts Boston and two anonymous reviewers for their comments and suggestions. All remaining errors are mine.
} 
Households in sub-Saharan Africa, whose livelihood heavily depends on agriculture and related activities, often diversify by engaging in farm and off-farm activities. The significance of the sub-sector is widely recognized in scholarly works even more so than in the policy making arena. In 2000s, three journals (World Development, 2001 on Latin America; Food Policy, 2001 on Africa, and Agricultural Economics, 2006 on Asia and Africa) devoted special issues to focus on the significance and determinants of off-farm activities in different parts of the world. Although less productive compared to modern sectors, the contributions of rural off-farm activities to economic growth, rural employment, and poverty reduction (Lanjouw and Lanjouw 2001), as well as to growth and welfare by slowing rural-urban migration (Lanjouw and Lanjouw 1999), are well documented. In Africa, studies indicate the role that off-farm activities play to help countries get out of poverty (Lanjouw, et. al. 2001) and to increase food consumption, as well as access more stable income and consumption over years (Reardon, et. al. 1992).

Although scholars seem to agree on the significance and importance of off-farm activities rural Africa, there seems to be no consensus regarding the most important factors that drive participation and intensity of off-farm activities (Ellis, 2000) and its definition (Barret, et. al. 2001a). There is no agreement on the terminologies used to refer to such activities. The same activities are referred to as off-farm or non-farm. Ellis (2000) defines the former as 'wage or exchange labor on others' farms, including payments in kind and cash' and the latter as 'non-agricultural income sources that includes non-farm rural wage or salary employment, non-farm self-employment income and remittances. In this paper, no distinction is made between non-farm and off-farm income, and the term off-farm is used to refer income sources included in both off-farm and non-farm ${ }^{10}$. In terms of factors driving off-farm activities, one of the hypotheses is that households engage in off-farm activities out of necessity; the other is that participation in off-farm activities is a choice to maximize profit. Still others argue that farmers engage in off-farm activities in response to policy shocks (Barrett, et. al. 2001). For instance, it has been indicated that the implementation of Structural Adjustment Program (SAP) and economic liberalization throughout sub-Saharan Africa during the last fifteen years has coincided with rapid expansion of rural income diversification (Bryceson 1999). During these reform periods, synergy between farm and non-farm activities in Africa have been documented in de Janvry (1994), Delgado and Siamwalla (1999), and Reardon et. al. (1994).

\footnotetext{
${ }^{10}$ The exception is that remittances are not included since it is not an income from supply of household resources. The activities may be agricultural or otherwise. In African economies, most off-farm activities are related to agricultural activities, since in rural part of most of these countries the main income source is agricultural activities. Other activities, like handicraft works and petty trading, are also heavily dependent on agricultural sector.
} 
In the context of rural Ethiopia where subsistence farming is common, off-farm activities serve as an alternative outlet to cope with unexpected income shortfalls. Given limited arable land, and low agricultural productivity to accommodate the high population growth, the significance of off-farm activities cannot be overstated. In rural Ethiopia, crop income accounts for the largest share of total income, $71 \%$, followed by share of off-farm income, $17 \%$, in 1994. In 1997 the share of crop income increased to $83 \%$ while that of off-farm income decreased to $7 \%$. Although the offfarm income share is low compared to other African countries, $7-17 \%$ is not a negligible percentage. On top of that, off-farm activities are opportunities that rural farmers fall on during times of crisis or production shortfalls. In recent years one can easily witness some responses to changes in policy that promote the role of the market, even in the rural setting where increased market participation has just begun to have an impact. Ethiopia undertook significant policy reforms starting in 1992 especially on policies related to the agricultural sector. The period since 1992 can be described as the period when the country opened up the market both domestically and globally, removed some trade barriers, lifted quantitative restrictions on trade and established institutions to support the export sector. With the launching of reform measures one can reasonably expect responses in income diversification including off-farm. These changes are expected to have an effect on farmers' labor allocation and diversification decisions as well. The significance of this study should be looked at with these backdrops.

The purpose of this study is, therefore, to examine the determinants of income diversification. I specifically looked into determinants of participation in and intensity of off-farm activities between 1994 and 1997 harvest years in Ethiopia. The two harvest years have been selected to coincide with the economic policy reform periods. The two years have also differences when it comes to agricultural production. Ethiopia had experienced bad weather condition in 1994 compared to 1997. As a result there was low production in 1994. These differences in weather condition may have implication for the degree and timing of off-farm activities in rural Ethiopia. This study attempts to provide an insight into how households responded to changes in policy reform and weather conditions. The results of this study attempt to answer the following questions: What were the key determinants of participation in and intensity of off-farm activities? Do households tend to engage more in the offfarm activities as a result of policy reforms or just a response to seasonal weather conditions? The remaining sections of the paper are organized as follows. Section II presents a brief review of literature and previous studies on Ethiopia. Section III provides a brief description of the model and model variables. Section IV discusses the data and estimation issues. Results of the estimation are presented in section $\mathrm{V}$. The last section provides concluding remarks and policy implications. 


\section{Literature review}

Despite the view that rightly associate rural off-farm sector as a low-productivity sector, recent years have witnessed a move towards recognition of its various roles (i.e. economic growth, rural employment, poverty reduction, and slowing rural-urban migration) (Lanjouw and Lanjouw, 2001; Lanjouw and Lanjouw, 1999). The significance of this sub-sector has also been manifested through the importance of non-farm wage labor (compared to self-employment), and local non-farm earnings (compared to earning by migrants) (Reardon 1997). Studies in Latin America also confirm the significance of the sub-sector. For instance, as indicated by Deininger and Olinto (2001), in Colombia, off-farm employment contributes a significant share $(45 \%)$ to household income, although the importance of off-farm income and returns to household labor vary over the range of income distribution. In Peruvian rural areas, $51 \%$ of the net income of rural households comes from these off-farm activities (Escobal 2001). In Honduras, income from non-farm wage and self-employment represents $16-25 \%$ of farm household income, and is especially important for middle and higher income strata (Ruben and van den Berg 2001). Related studies in other parts of Latin America also demonstrate similar results (Lanjouw 2000; Reardon, et. al. 2001, Yunez-Naude and Taylor 2001) ${ }^{11}$. Similar studies on African economies (more on this later) are scanty by growing as the importance of off-farm activities is appreciated at the level of policy makers.

Unlike agreement on the significance and importance of off-farm activities, there is no consensus on the most important factors that drive participation and intensity of offfarm activities (Ellis, 2000). Necessity and profit maximization are the two competing arguments as stated above. The view of the necessity hypothesis is that households engage in off-farm activities for survival, to secure basic needs during times of distress. Whereas, the choice hypothesis argue that the decision to engage in offfarm activities is determined by the return to labor in the labor market, as most household models predict. However, Ellis (2000) argues that, although the division of the determinants seems attractive, it is misleading since it attempts to assign the range of experiences to one process or another. For instance, given the rural settings in Africa, where there are constant fluctuations in weather conditions and farming determinants, farmers may engage in off-farm activities out of necessity when they are in distress; on the other hand, farmers may engage in off-farm activities by choice when there are favorable environment and if they have the necessary resources. Hence, it is difficult to have a clear-cut necessity-choice dichotomy as an argument. Others argue that farmers simply respond to underlying trends and

\footnotetext{
${ }^{11}$ Also see studies by Ellis $(1998,2000)$ that relate the issue of income diversification and off-farm activities to poverty, employment, and income distribution.
} 
processes when they make decisions to engage in off-farm activities, as opposed to decision process that looks into short-term objectives. These arguments make it difficult to come up with a list of major determinants that influence the decision process.

Barrett et. al. (2001a), without divulging into the dichotomy, argue that diversification into nonfarm activities emerges naturally from diminishing or time-varying returns to labor or land, from market failures or incomplete markets, from entry barriers to enter into high-return niches, from ex ante risk management, and from ex post coping with adverse shocks. They also indicate that diversification is understood as a form of selfinsurance in which people exchange some foregone expected earnings for reduced income variability. The latter could be achieved by selecting a portfolio of assets and activities that have low or negative correlation of incomes. However, it is difficult to strongly follow the argument of negative correlation of incomes for cases like rural Ethiopia where most of the off-farm activities highly correlate with agricultural activities. I expect to see that what is seen for the case of Ethiopia and other similar rural small farm setting is a combination of an ex post coping with adverse shocks and ex ante risk management.

Ellis (2000) also argues that classical household models do not capture intertemporal dimensions of livelihood strategies, and do not describe circumstances of survival under stress. According to Ellis, the following key factors should be taken into account as causes for diversification: seasonality, risk strategies, coping strategies, as well as labor and credit market conditions. Seasonality refers to the heavy reliance of farming on weather conditions and/or fluctuations in prices as a response to changes in demand and supply conditions. Seasonality in crop production and income results in some slack seasons during which farmers may have time to engage in off-farm activities. It is also possible that households diversify activities to ameliorate the threat to its overall welfare from risky concentration in a single (i.e. farm) activity. This coping strategy argument resembles that of the necessity reasoning, which states that household's diversification is a survival response to crisis or disaster. Market failures, which in the case of rural Africa are often the case for credit, labor and land markets, leave households with limited option to engage in offfarm activities to compensate for the market failures ${ }^{12}$. The absence of such markets requires households to take advantage of their demographic composition to use its resources effectively and to respond to market failures. Lack of functioning markets coupled with inter-temporal decision-making, and decisions under stress call for the aforementioned factors, which often are not included in the standard household

\footnotetext{
${ }^{12}$ In the case of Ethiopia, there is also complete absence of land market due to government ownership of land. This also requires households to find means to allocate other resources, mainly labor, to compensate for the absence of such markets.
} 
models. In addition to these key factors, other factors outside the control of households, including regional and local features, environmental factors, social and governmental factors, should also be considered in addressing the question of rural households' decision process.

Studies in Africa and other developing economies provide support for the significance of the above factors. For instance, access to public assets such as roads, and private assets such as education and credit, are pointed out as factors that encourage more participation and intensity (Escobal 2001; Lanjouw, et. al, 2001). These studies conclude that under the precarious conditions that characterize rural survival in many low-income countries, diversification has positive attributes for livelihood security that outweigh any implied cost associated with it. A study in Burkina Faso and Guinea shows that harvest shortfalls and terms of trade are found to drive diversification towards off-farm activities (Reardon, et. al 1992). Other studies indicate that a relative lack of capital (Abdulai and CroleRees 2001), entry barriers, lack of liquidity, market access, and skill constraints (Barrett, Reardon, and Webb. 2001) are some of the impediments to diversification, and to breaking the poverty trap in rural Africa. Barrett, et. al. (2001a) summarized various studies on Africa and concluded that there is a positive relationship between non-farm income share and total household income and land holdings. They contend that, in Africa, investment or asset (such as education, credit) requirement is a barrier to entry. Several studies echo similar sentiment about the impact of access to both public and private assets (Woldehanna and Oskam, 2001; Smith et al., 2001; Lanjouw, 2001; Matsumoto et. al, 2006; Kijima et. al, 2006; Abdulahi and CroleRees, 2001; Barrett, Bezuneh and Adbulahi, 2001). However, a recent study in Ethiopia claims that the entry barrier to non-farm activities is low and the general growth of non-farm subsector benefits the poor (Berg and Kumbi, 2006).

Only few studies specifically address the significance of off-farm activities in Ethiopia. The studies are either regional (Woldenhanna and Oskam 2001; Carswell 2002; Holden, Shiferaw and Pender 2004; Berg and Kumbi, 2006) or focus only on droughtprone villages (Dercon and Krishnan 1996, Block and Webb 2001). The latter two studies used similar nation-wide household survey data as the one employed in this study, but limited their analysis to very few sample households from drought-prone parts of the country. Using data from the southern part of Ethiopia, Carswell (2002) reported that women play a positive role in income diversification; in particular they contribute to diversify activities to cash incomes for poorer households. Dercon and Krishnan (1996) analyzed the different income portfolios of households using survey data from Ethiopia and Tanzania. The results of their study indicate that the different portfolios held by households cannot be explained by their behavior towards risk; it is better explained by differences in ability, location, and access to credit (Dercon and 
Krishnan, 1996). Their result, with respect to risk, is contrary to theoretical explanations (Ellis, 2000) and empirical findings (Block and Webb, 2001).

Block and Webb (2001), using 300 households from drought-prone parts of the country collected in 1989 and 1994, attempt to find which households increased their share of income from non-cropping activities the most during the inter-survey years. They find that wealthier households tend to have more diversified income streams; households with greater concentration of assets were more likely to fall in their relative income ranking (as were female-headed households). They also found that initially less diversified households subsequently realized greater gains in income diversification. Contrary to Dercon and Krishinan (1996)'s work, they find evidence that personal perceptions of risk factors guided subsequent diversification decisions. Using survey data from the northern part of the country, Woldenhanna and Oskam (2001) argue that farm incomes and off-farm incomes are substitutes. They divided the off-farm employment into off-farm wage employment and off-farm self employment and arrive at the finding that farm households diversify their income sources into off-farm wage employment as a result of low farm income and the availability of surplus family labor, whereas they enter into off-farm self employment to earn an attractive return (Woldenhanna and Oskam 2001). The present study did not distinguish wage off-farm activities from self-employment off-farm activities since the data does not allow for such grouping of off-farm activities reported in the survey.

Despite the increasing significance of off-farm activities and their increased importance as alternative income source, most previous studies address the problem and significance only from a static point of view. The dynamics in intensity and participation in off-farm activities in Africa have not been given due attention, especially when the underlying determinants change from time to time. These changes may be due to economic growth and economic policy reform (specifically, changes in farm input and output market situations).

The present study is different from previous studies in three aspects. First, the survey sites covered are representative of the main agricultural regions and the different cropping systems of the country (except pastoralist areas). Second, the survey years used in this study (1994 and 1997) were the periods in which the government undertook significant economic policy reforms, to which significant response is expected from farm households. Reform programs were launched in 1992 including liberalization of agricultural input and output markets (Lemi, 2009). Third, this study addresses not only determinants of intensity but also determinants of participation in off-farm activities during the two survey years. Unlike previous studies, this study also incorporates key factors implied by the literature including seasonality, risk strategy, 
farm activities (income), asset ownership, and demographics in the off-farm income estimation models.

\section{Model and model variables}

\subsection{Model}

Consider a standard utility maximization problem, where household members jointly choose their consumption $\left(C^{i}\right)$, where $\mathrm{i}=1,2, \ldots \ldots, 5$ for each household member (the average family size of each household is considered to be 5). Household members also decide on the allocation of their total time endowment, $\left(T^{i}\right)$ as in Sicular (1986)'s team labor allocation. Each member's time endowment is divided in to three activities: Leisure $\left(L^{i}\right)$, off-farm work $\left(O^{i}\right)$, and on-farm work $\left(F^{i}\right)$. Given income from farm work $\left(w^{i}\right)$, income from off-farm work $\left(y^{i}\right)$, and fixed capital stock of the household $\left(K_{o}\right)$, each household maximizes a utility function. Consider that the utility function is assumed to be additively separable, continuously differentiable, increasing, and concave in all of its arguments:

$$
\begin{aligned}
& \operatorname{Max} \mathrm{U}^{1}\left(C_{1}, L_{1} ; Z\right)+\mathrm{U}^{2}\left(C_{2}, L_{2} ; Z\right)+\mathrm{U}^{3}\left(C_{3}, L_{3} ; Z\right)+\mathrm{U}^{4}\left(C_{4}, L_{4} ; Z\right)+\mathrm{U}^{5}\left(C_{5}, L_{5} ; Z\right) \\
& C^{i}, L^{i}, O^{i}, F^{i}
\end{aligned}
$$

$Z^{i}$ is a vector of a household member's characteristics (like Gender, age, education, etc) that affects household preferences with respect to consumption, and leisure. As in Strauss (1986), equation (1) is maximized subject to budget constraint, and time constraint. Given these constraints, maximization results in the Marshallian household labor supply for farm and off-farm works as ${ }^{13}$ :

$$
\begin{aligned}
& F^{i}=F\left(w^{i}, y^{i}, k_{o}\right) \\
& O^{i}=O\left(w^{i}, y^{i}, k_{o}\right)
\end{aligned}
$$

This model is too simplistic since it assumes perfect information in all markets (i.e. output, labor, capital (credit), and land). Note also that it is assumed that income from farm and off-farm work will be spent partly on consumption and partly on accumulation of fixed capital. However, the time spent on farm work is affected by income from off-farm work and vise versa. One can consider a more sophisticated

\footnotetext{
${ }^{13}$ Since consumption and leisure time determinants are not the interest of the present study, their equation is not reported here.
} 
model by brining in time horizon, savings, borrowings, and labor hired on farm, among other things. But for this study, the purpose of this model is only to fix ideas and to give structure to the issue at hand. For estimation purposes, reduced form of (2) will be used. Since households is the unit of analysis in this study, the above equations will be aggregated over the superscript $i$ to get the value of each variable at household level. To get aggregate values for household characteristics, either average is taken, or head of the household characteristics is used as the case may be to get a figure that represent all household members.

In the absence of actual time allocation data, income received from farm and off-farm activities can be used as a proxy. The equation could be rearranged to define off-farm income as a function of other variables including variable $Z$ as key determinants of time spent (or income earned) from off-farm activities, given the income from farm work. The question is, therefore, what makes farm households to switch between farm and off-farm works or what makes them to engage in both types of works at the same time?

\subsection{Model variables}

As implied above, the key determinants that are believed to drive diversification to offfarm income sources in rural settings can be grouped into five: demographics, asset ownership, risk strategies, seasonality, and income from other sources (see Ellis, 1998, 2000). Specifically, one should take into account demographic composition of households in terms of age, gender and education level of household members. For asset ownership, livestock and land are the two major assets for farm households in rural Ethiopia ${ }^{14}$. Value of livestock that each household owns is used not only as a farm input but also as a saving. In the context of free market system, one would expect that access to assets promotes households to engage in off-farm activities more. However, in a situation where market is very thin or non-existence for some of these assets (like land, and labor), it is difficult to expect similar relationships. Moreover some of these may be suitable to agricultural sector than to off-farm activities. In the context of Ethiopia, since these assets are more suited for agricultural activities, we expect a negative relationship between these asset ownership and participation in and intensity of off-farm activities. Land holding is also one of the major farm inputs and is expected to play a significant role. In the context of Ethiopia, where farm households do not have ownership rights but only use rights, in some regions right to rent, farmers cultivate their own allocated land and/or rental

\footnotetext{
${ }^{14}$ Farm tools and rented in land are not included in asset ownership since very few households report these two assets and for those who report the values are too small to make significant difference in estimation.
} 
land from other farm households. To this effect, status of ownership - 'owned' or rented- may not matter in decision-making but rather what matters the most is quality of land and its impact on productivity.

For risk or risk aversion indicators it is difficult to think of a single variable to capture the degree of risk perception of all households in all survey sites. Farm households have different degrees of risk perception depending on their asset ownership and the degree of their vulnerability to weather conditions. Farmers may respond to risk by diversifying farming activities through planting different types of crops and/or by spending more time on farm to guarantee adequate food for the family. In this study, the degree of exposure to risk by households is captured using two variables. One of the signals for farmers to perceive risk is the quality of their land. This is captured by the weighted average of the quality of land indicator ${ }^{15}$ as reported by households. Some areas or plots are considered low quality for any crop, even after applying natural or man-made fertilizer, and that is how farmers categorized the plots into high, medium and low quality. It is expected that the lower the quality of land, the higher the possibility that farmers may experience crop failures. Farmers who own poor quality land are expected to engage in off-farm activities to guarantee food for their families from other sources in case of crop failure.

The other risk indicator used is the number of crops that farmers plant each year ${ }^{16}$. Farmers often diversify their crop production by planting different crops during a crop season as a mechanism to avoid crop failure risk in one or two crops. Even though some sites or villages are suitable for one of two crops for farmers to specialize in, there may be some unobservable and uncontrollable factors that diminish the chance of high yield even for those suitable crops. Farmers diversify even among those suitable crops. If there is only one or two crops to which farmers can diversify, they are likely subject to high risk. Hence, the total number of crops cultivated is used as another risk indicator. It may be that households may plant different crops to diversify to cash and staple crops, which again confirms that the reason for planting different crops is to secure enough food and cash income.

Seasonality is another factor that affects off-farm activities. Issues of seasonality could be within a given year or across years. Given the two major crop seasons

\footnotetext{
${ }^{15}$ Quality of land variable indicates degree of fertility of the land. Farmers were asked about the quality of each plot of land that they cultivate. Farmers respond one of the three answers for each plot: best quality (3), medium quality (2) and poor quality (1). Then I assigned the values in brackets for each level of quality. Finally, we calculate weighted average (the weight is size of each plot) of the quality of land for each household.

${ }^{16}$ The number of crops may be correlated with the number of plots that a farmer owns. However, in the dataset I have employed, I have only the total land size owned not the number of plots at the household level, and hence I can not determine if this is the case.
} 
(meher and belg), farmers may be idle during times other than the crop seasons. It is also important to note that due to different weather conditions year after year, we expect to see variations across years. As can be seen in Table A.4 in the appendix, different time periods had been used for each district to collect the data and hence the recall periods were different for each district. To account for this, dummy variables are created for survey periods and recall months. The season dummy variable takes value of 1 for a district if the survey was conducted in that district during the slack months of the year and takes 0 otherwise. The year dummy variable takes 1 for 1997 and 0 for 1994. As indicated in the descriptive statistics, farmers engage more in offfarm activities in 1994 compared to 1997. The key difference between these two years, when it comes to agriculture, is that year 1994 is considered as the year with sever weather conditions that was not favorable for agricultural production; the other difference was that year 1997 is considered as the year where farmers have been fully exposed to the policy reforms undertaken by the government. The year dummy is expected to pick these effects. Although it seems difficult to distinguish between the effects of the weather condition and the effect of policy change from the year dummy coefficient, I have also controlled for crop income to examine whether households are substituting farm and off-farm activities during the harvest years.

It is clear that one need to account for crop income received from farm activities per se in off-farm estimations. To account for income from the two crop seasons, values of crops produced during meher (main harvest season) and belg (slack season) are incorporated in estimation models. Having crop production alone may not be enough for cash-poor farmers; the amount of cash income from production also matters. It is important to somehow account for the actual cash income obtained from the sale of crop in each season, in addition to just controlling for total production. The amount of sale by each household may help explain not only the degree of market access but also their access to cash. However, variable that accounts for the actual income received from the sale is not available. Short of that, households were asked if they had sold any part of the harvested crops during each crop season. Using this information, one can create a dummy variable to indicate sale of part of the harvested crops during each season. Two dummy variables were created, one for those households who sold part of their crop during meher and the other for those who sold part of their crop during belg. There may be issue of endogeniety of crop income and off-farm income. It is not clear whether crop income determines off-farm income or the other way around. I have adopted appropriate estimation technique to respond to this concern. 
In addition to these key indicators, to capture regional and local effects that might affect decision-making, village dummies ${ }^{17}$ are added to each model either automatically through panel estimation model or manually by creating the dummy variables where appropriate. Village dummies help to capture difference in physical infrastructure, and access to markets, as well as differences in climate variation (i.e. drought-prone vs. surplus villages). The demographic variables include age of household head, age squared to capture experience and old age, dummy for femaleheaded households, dependency ratio ${ }^{18}$, family size in adult equivalents, the number of students in each household.

From the classical household models it is not clear which of these variables affect participation and which of them affect intensity of off-farm activities. The eclectic approach (Ellis, 1998 and 2000) also does not distinguish between determinants of participation and intensity for off-farm activities. This study will use Heckman twostage estimation technique to identify if there is any difference in factors that affect participation and intensity (more about the estimation approaches in the next section). Given the condition in Ethiopia, I expect to see negative effects from crop incomes due to competition between farm and off-farm activities over labor. For asset ownership, specifically agriculture related resources, I also expect to see negative effect as these resources (livestock and land) are more suitable for farm activities than off-farm. For risk indicators, it is expected that those households who face high risk situation ex ante (for instance, poor quality of land) may engage more in off-farm activities to ameliorate the impact of the risk.

\section{Data and estimation}

\subsection{Data and descriptive statistics}

Household survey data from rural Ethiopia during 1994 and 1997 harvest years are used in this study ${ }^{19}$. The Department of Economics at Addis Ababa University, in

\footnotetext{
17 There are a total of 19 villages and hence 18 dummies. The coefficients for the dummies are not reported here to save space.

${ }^{18}$ Dependency ratio is defined as ratio of family members below age 15 and above age 60 to total family size.

19 These two years were selected for two reasons. First, 1994 and 1997 give us a natural experiment where one can see the effect of both policy and weather shocks. It helps to see how farmers respond when they face these shocks at the same time. Second, the other two survey years in between (1995 and 1996) are too close to the base year to see any significant response from the farmers. The later years (especially
} 
collaboration with various institutions (University of Oxford, UK and International Food Policy Institute (IFPRI), USA), has collected socio-economic data from 1500 representative farm households in Ethiopia since $1989^{20}$. With only few attrition, about 1450 households are used for each the two survey years in this study. The survey, which gathers information from the same households, is in its sixth round (although not on a regular interval). The core modules that appear on the questionnaires are information on demographics, assets, farm inputs, farm outputs, livestock, and health indicators. The survey covers six regions (formerly regions $1,3,4,7,8$, and 9$)^{21}$ and fifteen sites representing the different ecology of the highland farming systems in the country with the exception of pastoral systems. Table A.4 in the appendix displays the survey sites, the main harvest months and the time of interview for the first four rounds. Given the different times of survey for each district in each region, response of farmers on recall questions may be different since recalls of up to four months were asked. Most surveyed areas have two crop seasons: the main season (meher) and the slack season (belg). The different survey times for each district may raise issue of seasonality; hence it needs to be accounted for in estimation.

During both survey years, households were asked questions specific to their participation in off-farm activities ranging from the location of the activities to the reasons why other family members were not seeking off-farm employment. Information on the income earned from these activities, both in cash and in kind, was gathered from each household. Tables A.1 and A.2 in the appendix provide participation rates and reasons for not participating in off-farm activities, respectively, both by region and year. Off-farm activities participation rate declined from its $35 \%$ in 1994 to $23.6 \%$ in 1997, with significant variation across regions. For instance, in Tigray region participation rate dropped from almost $71 \%$ to $19 \%$, in Oromia region participation dropped from $45 \%$ to $23 \%$ whereas in Amhara and SNNP, participation rate remained almost constant over the two years period (see Table A.1). The difficulty of access to off-farm activities outside of farmers' residential locality were manifested by the fact that, during both survey years, over $74 \%$ of households reported that they participated in off-farm activities only in their villages.

1999 and 2000) may be ideal to conduct longer panel analysis and they may also introduce other shocks. However, for these years some of the variables that refer to demographics and household composition and related covariates are not consistent with previous year variables and it creates difficulty to pool the data together from these years. In addition, given the length of time between 1994 and 2000 (and later years for that matter) other significant changes, other than policy reform and weather condition, might have occurred to influence famers to respond and hence it creates difficulty to distinguish responses to policy and other factors that sets during these periods.

${ }^{20}$ The 1989 survey covered only six (drought-prone sites) of the fifteen sites covered during the other survey years. The next four surveys were conducted in 1994, 1995, 1996 and 1997.

${ }^{21}$ These regions were later named as Tigray (for region1), Amhara (for region 3), Oromia (for region 4) and Southern Nation and Nationalities People (SNNP) (for regions 7, 8 and 9). 
Pervious study done in the southern part of the country shows that the single most important non-farm activity was trading and laboring for others (Carswell, 2002); this was also found to be significant in these surveys. The major activities in which farm households engaged in during the 1994 and 1997 harvest years were farm work (i.e. on others' farm), labor sharing activities ${ }^{22}$, laboring (skilled builder, thatcher) and other unskilled activities. In 1997 there was an increase in participation in skilled labor and unskilled labor activities; and there was a decrease in participation in food-for-work and labor sharing activities. This trend is expected, because as the size of per capita land holding gets smaller, family members needed to engage in those off-farm activities with limited entry barriers, especially for resource-poor households. This confirms what is indicated in the literature, especially for households in rural Africa. The decline in food-for-work may be due to good crop harvest in 1997 compared to 1994.

Farm households were also asked why they participated in off-farm activities during the 1997 harvest year. One of the main reasons for participating in off-farm activities was limited agricultural income (over $68 \%$ of the responses). This supports the view that farm and off-farm incomes are complements for households with limited access to other resources like asset and credit. In response to the question as to why some members of the household were not seeking off-farm jobs in 1994 and 1997 harvest years, farmers point out two reasons as major impediments: lack of employment opportunities, and competition for labor by farm and off-farm activities. The number of households who reported lack of employment opportunities decreased in 1997 for all regions, whereas those who reported competition between farm and off-farm activities increased in 1997 (see Table A.2 in the appendix). This is consistent with the substitution hypothesis, which argues that when there is favorable weather, offfarm employment opportunities increase and at the same time demand for on farm labor increases. There are some regional variations in terms of the reasons for participating and not participating in off-farm activities. For instance, with some variations, some regions report taboo as one of the reasons for not participating in such activities in 1994 but not in 1997 (see Table A.2).

The key variables for this study are share of income from different sources. In a rural setting, income sources can be broadly divided into three: crop income, off-farm income, and livestock income. Livestock income refers to income from byproducts of live animals including milk, butter, eggs as well as hides and skins. Some households received income for off-farm activities in kind. We have converted all payments

\footnotetext{
${ }^{22}$ Traditionally, labor sharing activities do not involve payments in cash or kind. Families exchange labor on each others farm for different activities. Off-farm income does not capture this labor allocation unless households receive some kind of payments in in cash or in kind.
} 
received in kind into cash using price and unit conversion factors collected at nearby markets for each district. Table 1 presents descriptive statistics for the different sources of income during 1994 and 1997 harvest years in Ethiopia. For the three sources of income, mean, median, and inter-quartile ranges are reported for total, per capita and share of each income source. During the 1997 harvest year, when weather condition was suitable for farming, the share of off-farm activities significantly dropped from over $18 \%$ in 1994 to only $7 \%$ in 1997. In absolute terms, the average income received from off-farm activities was also lower in 1997 (birr ${ }^{23}$ 97) compared to year 1994 (birr 107) (see Table 1). There were regional variations in terms of average off-farm income during the two harvest years; in 1994, part of southern region (region 7) had the highest average off-farm income (birr 168) followed by Oromia (birr 128). However, during the same year the share of off-farm income in total income was highest for Tigray (0.62) followed by part of Southern region (region 7) (0.26). In 1997, for all regions the share of off-farm income declined from its 1994 levels. Total crop income more than doubled in 1997 compared to its value in 1994. The opposite was true for the share of off-farm income. The median values of total off-farm and per capita off-farm incomes were zero in 1997, which is expected since farmers switched to farm income during this year. The fact that the survey sites had zero median values and positive skewness suggests that income values have relatively few high values but with long tails to the right. In 1997 skewness increased for two of the three income sources. However, unlike in 1997, in 1994 when the necessity argument seems to dominant, poor households engaged more in off-farm activities.

Table 1. Mean, Median, and Inter-Quartile Range (IQR) of total and per capita incomes from different source in rural Ethiopia during 1994 and 1997 survey years.

\begin{tabular}{lrrrrrr}
\hline \multirow{2}{*}{ Income Source } & \multicolumn{3}{c}{$\mathbf{1 9 9 4}$} & \multicolumn{3}{c}{1997} \\
\cline { 2 - 7 } & Mean & Median & Skewness & Mean & Median & Skewness \\
\hline Off-Farm, Total & 107.19 & 25.00 & 7.3 & 96.61 & 0.00 & 7.3 \\
Crop, Total & 1394.7 & 573.4 & 15.3 & 3383.3 & 1203.6 & 29.7 \\
Livestock, Total & 52.47 & 0.00 & 6.0 & 65.81 & 0.00 & 6.9 \\
& & & & & & \\
Per Capita Off-Farm & 20.44 & 4.32 & 10.4 & 15.78 & 0.00 & 6.9 \\
Per Capita Crop & 233.92 & 106.54 & 5.9 & 443.79 & 180.9 & 27.4 \\
Per Capita Livestock & 9.74 & 0.00 & 6.3 & 10.41 & 0.00 & 7.9 \\
& & & & & & \\
Share Of Off-Farm & 0.18 & 0.03 & 1.8 & 0.07 & 0.00 & 3.6
\end{tabular}

${ }^{23}$ Birr is the Ethiopian currency. The exchange rate as of October 2007 was $\$ 1=9.0$ birr. 


\begin{tabular}{lrrrrrr} 
Share Of Crop & 0.71 & 0.87 & -1.1 & 0.83 & 0.96 & -2.0 \\
Share Of Livestock & 0.06 & 0.00 & 4.2 & 0.05 & 0.00 & 4.4 \\
\hline
\end{tabular}

Off-farm, total= total off-farm income (both in cash and in kind earnings); crop, total = total value of crops harvested; livestock, total $=$ total income received from sale of livestock products (like milk and hides and skin). Values are in Ethiopian currency (birr). The exchange rate was about $\$ 1=5.42$ birr in 1994 and $\$ 1=6.1$ birr in 1997 .

One has to also note that both off-farm and crop income sources are mostly dependent on weather conditions (mainly reliable rainfall) since rural off-farm activities are highly linked to agricultural activities. Hence, it is not appropriate to attribute all the variability and dynamics of income sources over time only to the rational or irrational behavior of farmers. For example, the 1994 harvest year was considered as a relatively low production year due to relatively bad weather condition. During a good weather year, resource-poor farmers are expected to spend more time on crop production on their farm to have enough food production for the season not only for consumption but also as a source of cash income. For such resource-poor farmers, more labor time and resource spent on own farms lower their participation in off-farm activities. This descriptive statistics seem to support the idea that, in countries like Ethiopia, participation in off-farm activities is mostly as survival mechanisms rather than a choice ${ }^{24}$. The next section will present the methodology and estimation approaches employed in obtaining participation and intensity coefficients.

\subsection{Estimation}

Equations estimated in this study have the following forms:

$$
\begin{aligned}
& y_{i t}=\alpha X_{i t}+\beta Z_{i t}+\varepsilon_{i t} \text { (participation equation) } \\
& y_{i t}^{o}=\phi X_{i t}+\varphi W_{i t}+\eta_{i t} \text { (Intensity Equaion) }
\end{aligned}
$$

For estimation of participation equation, $y_{\text {it }}$ is dummy variable, which takes 1 for participating households and 0 otherwise. For estimation of intensity equation, $\mathrm{y}^{\mathrm{o}}{ }_{\mathrm{it}}$ is the share of off-farm income to total income, and it is observed only when $y_{i t}=1$. $X_{i t}$ is a vector of explanatory variables common for both equations. $Z_{\text {it }}$ is a vector of explanatory variables that affect only participation but not intensity, where as $W_{i t}$ is a vector of explanatory variables that affect only intensity. For joint estimation of both

\footnotetext{
${ }^{24}$ There may be resource-rich farmers, in labor, land, and livestock, who engage in off-farm activities as a choice, since they can engage in both activities simultaneously. Nonetheless, the types of activities that these farm households - resource-poor and resource-rich - engage in may be different. Resource-rich farmers may engage in lucrative activities since they participate in these activities by choice not for survival. It is beyond the scope of this study to distinguish the activities by the type of farm households in each site.
} 
equations, there should be at least one variable that is not common for both equations. We have identified one variable, dependency ratio, which affects only participation. The logic behind this is that households know ahead of time if their family labor composition allows them to participate in off-farm activities or not. Although households with large dependent ratio want to participate more in off-farm activities to secure enough food for the family, the available resource (i.e. human capital) doesn't allow them to do so. Large dependency ratio is a barrier to participation since dependent family members are not participating in any of the activities and the other members of the household have to make sure there is enough food production for the family members by spending more time on farm, not on offfarm. It may also be the case that household members spend time looking after the dependents and hence have less time to spend on off-farm activities.

There are two econometric issues that need to be addressed in estimating the above equations: endogeniety, and selection bias ${ }^{25}$. The endogeniety issue arises from the suspicion of dependence between off-farm and farm activities. Especially for resource-poor farmers who cannot perform both activities at the same time, it is reasonable to expect that engaging in one activity preclude farmers from other activities. It is necessary to test for exogenity of the suspected variables. The issue of self-selection bias may be due to those households who did not report participation in off-farm activities and who may be considered as if they didn't want to participate in off-farm activities at all. However, it may be the case that they may want to participate if some conditions were fulfilled. Hence, it would be an unfair assessment to consider those with zero off-farm income as if they didn't want to participate under any circumstance. They might have some reservation income from the off-farm activities, and if the market income from off-farm is below that income, they may not participate in off-farm activity. In this study, we first examine the severity of the issues (selection bias and endogenity), and where appropriate, we attempt to account for the issues using appropriate technique. For the issue of self-selection bias, initially I employed Heckman's two stage estimation technique to estimate both the selection and intensity equations. From the Heckman two-stage estimation, significant of the selectivity variable (mills lambda) confirms the existence of selectivity bias. The Heckman selection model is a two-equation model as in the following equations,

$$
\begin{aligned}
& y=\beta X+\varepsilon_{1} \\
& Z^{*}=\alpha W+\varepsilon_{2}
\end{aligned}
$$

\footnotetext{
${ }^{25}$ Given the nature of the data, one may suspect issues related to outliers. Quantile estimation technique would be the appropriate estimation technique for outliners. However, Hausman's specification test indicates that quantile regression is not the best fit to explain the data.
} 
where $\varepsilon_{1} \sim N(0, \sigma), \varepsilon_{2} \sim N(0,1)$, and $\operatorname{corr}\left(\varepsilon_{1}, \varepsilon_{2}\right)=\rho$

Where $y$ is observed if and only if a second unobserved latent variable, $Z^{*}$, exceeds some threshold level. The first equation is participation equation, where $y$ takes 1 if a household participates in off-farm activities and 0 otherwise. The second is the selection equation. When $\rho=0$, OLS regression provides unbiased estimates, when $\rho \sim=0$ the OLS estimates are biased. The Heckman selection model allows us to use information from non-participating households to improve the estimates of the parameters in the intensity regression model. The Heckman selection model provides consistent, asymptotically efficient estimates for all parameters in the model.

However, the Heckman two-stage estimators sometimes perform poorly (Nawata and Nagase, 1996). Alternative estimation technique should be used to see robustness of the results. Heckman's second stage estimation does not account for the panel nature of our data; it only estimates the selection equation with additional information variable from the participation equation using OLS. Another way to take advantage of the information hidden in the data for the non-participants and also to use the panel nature of the data is to employ panel-Tobit estimation technique.

Panel-Tobit estimation technique is as follows.

$y_{i t}=x_{i t} \beta+v_{i}+\varepsilon_{i t}$, for $i=1, \ldots, n_{i} \cdot v_{i}$ are iid $\mathrm{N}\left(0, \sigma_{v}{ }^{2}\right)$, and $\varepsilon_{\text {it }}$ are iid $\mathrm{N}\left(0, \sigma_{\varepsilon}{ }^{2}\right)$

The observed variable $y_{i t}^{o}=\left\{\begin{array}{l}y_{i t} \text { if } y_{i t}>0 \\ 0 \text { otherwise }\end{array}\right.$ represents censored version of $y_{\text {it. }} v_{\mathrm{i}}$ represents time-invariant (observed or unobserved) factors and $\varepsilon_{\text {it }}$ represents the overall error term. It is assumed that $E\left(v_{i} v_{j}\right)=0, E\left(v_{i} \varepsilon_{i t}\right)=0$, and that $E\left(\varepsilon_{i t} \varepsilon_{j t}\right)=0$ for all $i$ and $j$; that means there is no correlation between error terms and there is no autocorrelation. For this study the data is left censored for those households who did not report any income from off-farm activities.

I have approached the issue of endogenity in two ways. First, I attempted to run regressions with and with out those variables suspected of being endogenous in each specification (i.e. crop incomes). If comparing the two results generates no significant differences in the magnitude and signs of the coefficients, one may assume that the issue of endogenity is not severe. I have also estimated the equations using Tobit Instrumental Variable (IV) technique that accounts for the censored values of the data as well as endogenity. To compare consistency and efficiency of the estimation techniques adopted in this study, Hausman's specification test is employed. Heckman's two-stage and panel-Tobit estimation techniques are compared to 
alternative standard random effects model, quintile models, and Tobit instrumental estimation techniques. In all cases, Heckman's two-stage and panel-Tobit become the best specifications to explain the data ${ }^{26}$.

Hence, I have reported estimation results from different specification with and with out crop income to show robustness of the results. For Heckman two-stage estimation, village dummies are created and incorporated in each specification to account for village specific effects. Coefficients from the village dummies are not reported to save space. Results are reported in Tables 2-4. Table 2 presents Heckman's $1^{\text {st }}$ stage estimation, which uses probit model. Table 3 presents the second stage of Heckman's estimation model, which incorporates mills lambda. In Table 4, in addition to panel-Tobit estimation results, standard random effects estimation results, which don't account for censored values, are also reported for purpose of comparison. For both the probit and panel-Tobit estimation models, marginal effects are reported, instead of the raw coefficient, to make interpretation of the coefficients easier.

\section{Results}

One result that stands out consistently in all specification is the effect of the dummy variable for year 1997. From the panel-Tobit result, during 1997 harvest year, compared to 1994, share of off-farm decreased by over 0.25 points (Table 4 ). The negative and significant coefficient of the year dummy in both participation and intensity equations confirm that households engage in off-farm activities as a substitute for farm activities. They tend to engage less in off-farm activities during a year with relatively favorable weather condition. During 1994 harvest year, with relatively bad weather conditions, farmers had to practice off-farm activities to fill the income gap created by crop failures. Hence, off-farm activities were practiced for subsistence as a substitute for farm activities, whereas in 1997, with relatively better weather conditions (at least compared to 1994), farmers engaged less in off-farm activities. Could this be due to response to the favorable policy change in 1997? Due to the heavy dependence of the agricultural sector on weather conditions, it is difficult to say if there is systematic dynamism in off-farm activities in rural Ethiopia as a response to policy reforms. It seems rather a response to changes in the underlying weather conditions and farm activities. Even if we assume some positive response to the change in policy in 1997, the reform had the impact of encouraging farm activities than off-farm activities.

\footnotetext{
${ }^{26}$ Regression results from quintile and Tobit IV models are not reported to save space. The results are available up on request.
} 
These results are in line with Matsumoto, et. al. (2006)'s conclusions in that only lowpotential agricultural areas are more likely to participate in local nonfarm activities. In our case the year 1994 naturally became low-potential due to rain failure in most part of the country. Evidence from Uganda also alluded to this fact, where only low skilled workers tend to use off-farm activities to mitigate negative shocks in the traditional production (Kijima et. al., 2006).

Results for off-farm participation (Table 2) reveal that demographics, seasonality, asset ownership, and risk are the major determinants of participation in off-farm activities. Note that the impact from crop income is statistically zero. If any thing, it is the sale of crop during the meher season that led farmers to participate less in offfarm activities. Of the demographic factors, households with more dependents, and who are female-headed, tend to participate less in off-farm activities. A one point increase in dependency ratio decreases the probability of participation by about 0.33 points. One can safely say that these variables, large dependents and female headed, characterize poor farm households in rural Ethiopia (see for instance, Lemi, 2009). Although Carswell (2002) reported positive role that women play in diversification, the result I presented about female headed families may not be contradicting Carswell's finding. There are two reasons: first, Carswell (2002) considers the role of women within a household who could well be male headed households. Second, Carswell's study draws its data only from the southern part of the country, where enset farming system dominates and where most of the activities are undertaken by women. Age has a positive but insignificant effect; the negative and significant coefficient of the square term implies declining effect of age on participation. As head of the family gets older families participate in off-farm activities at a decreasing rate.

Table 2. Determinants of participation in off-farm activities in Ethiopia: Marginal effect of Heckman's $1^{\text {st }}$ stage estimation (dependent variable is dummy for off-farm employment)

\begin{tabular}{lccc}
\hline & $\begin{array}{c}\text { Without crop } \\
\text { income }\end{array}$ & $\begin{array}{c}\text { Without crop } \\
\text { sale dummy }\end{array}$ & $\begin{array}{c}\text { With crop income } \\
\text { and crop sale } \\
\text { dummy }\end{array}$ \\
\hline Demographics & 0.02 & 0.01 & 0.01 \\
Age of head & $(1.62)$ & $(1.61)$ & $(1.51)$ \\
Age of head squared & $-0.001^{* * *}$ & $-0.001^{* * *}$ & $-0.001^{* * *}$ \\
Female headed & $(-2.67)$ & $(-2.67)$ & $(-2.59)$ \\
Number of students & $-0.35^{\star * *}$ & $-0.35^{\star * *}$ & $-0.36^{* * *}$ \\
& $(-5.27)$ & $(-5.29)$ & $(-5.39)$ \\
Family size (in Adult equivalents) & 0.0001 & 0.0001 & 0.0001 \\
& $(0.15)$ & $(0.10)$ & $(0.06)$ \\
& 0.02 & 0.02 & 0.02 \\
& $(1.41)$ & $(1.42)$ & $(1.41)$
\end{tabular}


0.07 points. This result is unexpected. One expects to see that the better the quality of land, the more farmers stay on farm and participate less in off-farm activities. But the results reveal otherwise. One possible explanation for this is that if the quality of land is good, farmers may not have to spend that much time and resource to secure enough food for the family. That gives farmers some extra time to spend on off-farm activities. Similar results are also obtained in the intensity estimation equations. This result is consistent with the risk aversion argument, where farmers with poor quality of land need to spend more time on farm to guarantee enough food for family members. The other risk aversion indicator is number of crops that farmers plant during a given year. The coefficient of the number of crops is insignificant, although negative, in participation equation. The negative sign is consistent with the risk aversion hypothesis. The link between risk aversion behavior and the number of crops planted is more apparent in the intensity estimation results.

The only significant crop income variable in the participation equation is dummy variable for meher sale in the last specification. Value of crop income from both meher and belg harvest seasons do not affect participation decision. But sale of crop from meher season makes households to participate less in off-farm activities. Value of crop production is not enough to persuade farm households to stay on farm (to participate less in off-farm activities), but it is the sale of part of their crop production. In which case, off-farm and farm activities become substitutes, not complements. Similar, and even stronger, result confirms this argument in the intensity estimation results. This result is in line with the idea that mainly cash-poor farmers tend to engage more in off-farm activities, ceteris paribus.

Table 3. Determinants of share of off-farm income (intensity of off-farm activities) in Ethiopia: Heckman $2^{\text {nd }}$ stage OLS estimation results (dependent variable is share of off-farm income)

\begin{tabular}{lccc}
\hline \multicolumn{1}{c}{ Off-farm Share } & $\begin{array}{c}\text { Without crop } \\
\text { income }\end{array}$ & $\begin{array}{c}\text { Without crop sale } \\
\text { dummy }\end{array}$ & $\begin{array}{c}\text { With crop income and } \\
\text { crop sale dummy }\end{array}$ \\
\hline Demographics & 0.0001 & 0.0001 & 0.0001 \\
Age of head & $(0.93)$ & $(0.77)$ & $(0.14)$ \\
Age of head squared & -0.001 & -0.001 & -0.001 \\
Female headed & $(-1.01)$ & $(-0.88)$ & $(-0.35)$ \\
Number of students & -0.02 & -0.01 & -0.01 \\
& $(-0.41)$ & $(-0.40)$ & $(-0.24)$ \\
Adult equivalent & $0.02^{* *}$ & $0.02^{* *}$ & $\left(2.02^{* *}\right.$ \\
Seasonality & $(2.20)$ & $(2.47)$ & 0.001 \\
Season & 0.001 & 0.001 & $(0.79)$ \\
Year 1997 dummy & $(0.27)$ & $(0.73)$ & $0.08^{* * *}$
\end{tabular}




\begin{tabular}{|c|c|c|c|}
\hline \multicolumn{4}{|l|}{ Asset Ownership } \\
\hline Total land owned & $\begin{array}{l}0.0001 \\
(0.91)\end{array}$ & $\begin{array}{l}0.0001 \\
(0.88)\end{array}$ & $\begin{array}{r}0.0001 \\
(0.43)\end{array}$ \\
\hline Value of livestock & $\begin{array}{c}-0.001^{* * *} \\
(-4.52)\end{array}$ & $\begin{array}{c}-0.001^{* * *} \\
(-3.95)\end{array}$ & $\begin{array}{l}-0.001^{* * *} \\
(-3.72)\end{array}$ \\
\hline \multicolumn{4}{|l|}{ Risk Indicator } \\
\hline Number of crops & $\begin{array}{r}-0.02^{* * *} \\
(-8.50)\end{array}$ & $\begin{array}{r}-0.02^{* * *} \\
(-6.78)\end{array}$ & $\begin{array}{l}-0.01^{\text {***}} \\
(-5.63)\end{array}$ \\
\hline Quality of land & $\begin{array}{c}0.07^{* * *} \\
(5.34)\end{array}$ & $\begin{array}{l}0.07^{* * *} \\
(5.48)\end{array}$ & $\begin{array}{l}0.06^{* * *} \\
(5.22)\end{array}$ \\
\hline \multicolumn{4}{|l|}{ Crop Income } \\
\hline Value of meher crops & & $\begin{array}{l}-0.001^{* * *} \\
(-6.00)\end{array}$ & $\begin{array}{l}-0.001^{\text {***}} \\
(-5.16)\end{array}$ \\
\hline Value of belg crops & & $\begin{array}{l}0.001^{* *} \\
(2.43)\end{array}$ & $\begin{array}{l}0.001^{* *} \\
(2.37)\end{array}$ \\
\hline Meher sale dummy & & & $\begin{array}{l}-0.15^{\star * *} \\
(-6.73)\end{array}$ \\
\hline Belg sale dummy & & & $\begin{array}{r}-0.03 \\
(-1.50)\end{array}$ \\
\hline Constant & $\begin{array}{r}0.0001 \\
(0.03)\end{array}$ & $\begin{array}{r}0.04 \\
(0.31)\end{array}$ & $\begin{array}{r}0.11 \\
(0.94)\end{array}$ \\
\hline Mills lambda & $\begin{array}{l}0.23^{*} \\
(1.65)\end{array}$ & $\begin{array}{r}0.22 \\
(1.59)\end{array}$ & $\begin{array}{r}0.17 \\
(1.29)\end{array}$ \\
\hline $\bar{N}$ & 2901.00 & 2901.00 & 2901.00 \\
\hline $\mathrm{N}$-censured & 1643.00 & 1643.00 & 1643.00 \\
\hline Chi2 & 890.48 & 944.81 & 1071.66 \\
\hline Rho+ + & 0.78 & 0.76 & 0.64 \\
\hline
\end{tabular}

For the demographic factors, unlike the results from the second stage Heckman model (Table 3), the panel-Tobit and random effects (Table 4) most coefficients are statistically significant although the signs of the coefficients are the same. This is expected since the second stage Heckman estimation uses OLS model but accounts for the selection bias with mills lambda. Furthermore, in the second stage Heckman model mills lambda is significant only in the first specification. Once we incorporate crop income and sale of crops from both seasons, mills lambda became insignificant and hence there is no selection bias concern ${ }^{27}$. For the off-farm intensity results, as expected, there are some differences between the results reported from panel-Tobit and those from random effects models (Tables 4). As indicated above, Hausman's specification test confirms that panel-Tobit is the best specification for the data. Both specifications have the same signs for the coefficients but the results in the random effects model are weaker. Since results from the second stage of Heckman model are more or less similar (at lease in terms of the signs of the coefficients) to that of

\footnotetext{
${ }^{27}$ Mills lambda is the product of rho and sigma. Its insignificance in the last two estimation equations indicates that there is no selection bias. However, the value of rho (the correlation between the error terms of the two equations) is not close to zero, which indicates that there is correlation between the two errors. Since I have used two-step estimation for the Heckman model, likelihood test for the value of rho is not generated.
} 
the panel-Tobit and to the random effects model, I only discuss results from panelTobit model below to save space.

One of the variables, that had no effect on participation but affect intensity of off-farm activities significantly, is the number of students in a household. An increase in the number of students in a household by one unit increases the share of off-farm income by over 0.01 points. Could it be because some of these off-farm activities require some education? There are some activities, like trading and professional works, that require some kind of skill, which attracts those households with kids in school to help them out with some of the skill requirements. The positive impact of education is consistent with result from previous studies (Escobal, 2001 and Lanjouw et. al. 2001). Age of household head coefficient also becomes stronger compared to results in participation estimation; age affects intensity of off-farm activities positively but at a decreasing rate as head of the household becomes older. Unlike the results in participation equation, seasonality also plays a significant role in the intensity equations. Off-peak months are the best time to engage in off-farm activities for households who already decided to participate in off-farm activities. The year 1997 is also a year when households engaged less in off-farm activities in line with the result in the participation equation. Previous studies also argue that harvest shortfall (as in 1994) drive farmers to diversify more (Reardon, et. al. 1992), and when there is suitable farming condition, farm activities competes with off-farm activities (Woldehanna and Oskam, 2001). As in the participation results, an increase in the value of livestock also lowers off-farm intensity.

Table 4. Determinants of intensity of off-farm activities in Ethiopia: Results from panelTobit and random effects estimation models (dependent variable: share of offfarm income)

\begin{tabular}{|c|c|c|c|c|c|c|}
\hline & \multicolumn{3}{|c|}{ Panel-Tobit Estimations } & \multicolumn{3}{|c|}{ Random Effects Estimations } \\
\hline & 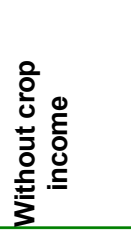 & 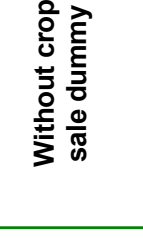 & 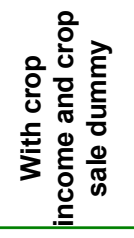 & 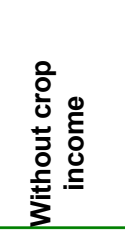 & 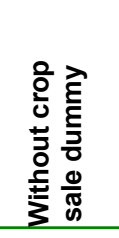 & 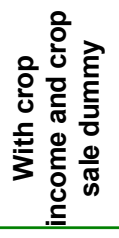 \\
\hline \multicolumn{7}{|l|}{ Demographics } \\
\hline Age of head & $\begin{array}{r}0.01^{* * *} \\
(2.62)\end{array}$ & $\begin{array}{l}0.01^{* *} \\
(2.36)\end{array}$ & $\begin{array}{l}0.01^{* *} \\
(2.38)\end{array}$ & $\begin{array}{r}0.001^{\star *} \\
(2.20)\end{array}$ & $\begin{array}{r}0.001^{\star *} \\
(2.23)\end{array}$ & $\begin{array}{l}0.001^{*} \\
(1.86)\end{array}$ \\
\hline Age of head squared & $-0.001^{* * *}$ & $-0.001^{* * *}$ & $-0.001^{* * *}$ & $-0.001^{* *}$ & $-0.001^{* *}$ & $-0.001^{* *}$ \\
\hline Female headed & $\begin{array}{r}(-3.08) \\
-0.09^{* * *} \\
(-3.88)\end{array}$ & $\begin{array}{r}(-2.86) \\
-0.09^{* * *} \\
(-3.81)\end{array}$ & $\begin{array}{r}(-2.93) \\
-0.09^{* * *} \\
(-4.17)\end{array}$ & $\begin{array}{l}(-2.40) \\
-0.03^{\star *} \\
(-2.27)\end{array}$ & $\begin{array}{l}(-2.39) \\
-0.02^{* *} \\
(-2.08)\end{array}$ & $\begin{array}{r}(-2.17) \\
-0.03^{* * *} \\
(-2.74)\end{array}$ \\
\hline Number of student & $\begin{array}{l}0.02^{\star *} \\
(2.57)\end{array}$ & $\begin{array}{l}0.02^{* *} \\
(2.19)\end{array}$ & $\begin{array}{l}0.02^{* *} \\
(2.18)\end{array}$ & $\begin{array}{l}0.01^{* *} \\
(1.97)\end{array}$ & $\begin{array}{l}0.01^{* *} \\
(2.05)\end{array}$ & $\begin{array}{l}0.01^{* *} \\
(2.00)\end{array}$ \\
\hline Adult equivalent & $\begin{array}{r}0.01 \\
(1.61)\end{array}$ & $\begin{array}{l}0.01^{* \star} \\
(2.31)\end{array}$ & $\begin{array}{l}0.01^{* *} \\
(2.22)\end{array}$ & $\begin{array}{l}0.001 \\
(1.13)\end{array}$ & $\begin{array}{l}0.001 \\
(1.07)\end{array}$ & $\begin{array}{l}0.001 \\
(1.46)\end{array}$ \\
\hline \multicolumn{7}{|l|}{ Seasonality } \\
\hline Season & $\begin{array}{r}0.06^{* * *} \\
(2.68)\end{array}$ & $\begin{array}{l}0.05^{\star *} \\
(2.36)\end{array}$ & $\begin{array}{c}0.04^{*} \\
(1.89)\end{array}$ & $\begin{array}{r}0.04^{* * *} \\
(3.15)\end{array}$ & $\begin{array}{r}0.03^{* * *} \\
(2.80)\end{array}$ & $\begin{array}{r}0.04^{* * *} \\
(3.18)\end{array}$ \\
\hline Year 1997 dummy & $\begin{array}{l}-0.28^{* * \star} \\
(-14.45)\end{array}$ & $\begin{array}{l}-0.28^{* \star \star} \\
(-14.25)\end{array}$ & $\begin{array}{l}-0.25^{\star * \star} \\
(-12.74)\end{array}$ & $\begin{array}{l}-0.11^{* * *} \\
(-11.91)\end{array}$ & $\begin{array}{l}-0.11^{* * *} \\
(-11.74)\end{array}$ & $\begin{array}{l}-0.10^{\star \star *} \\
(-10.23)\end{array}$ \\
\hline
\end{tabular}




\begin{tabular}{|c|c|c|c|c|c|c|}
\hline \multicolumn{7}{|l|}{ Asset Ownership } \\
\hline Value of livestock & $\begin{array}{r}-0.001^{* * *} \\
(-8.89)\end{array}$ & $\begin{array}{r}-0.001^{* * *} \\
(-8.08)\end{array}$ & $\begin{array}{r}-0.001^{* * *} \\
(-7.89)\end{array}$ & $\begin{array}{r}-0.001^{* * *} \\
(-8.18)\end{array}$ & $\begin{array}{r}-0.001^{* * *} \\
(-7.99)\end{array}$ & $\begin{array}{r}-0.001^{* * *} \\
(-7.88)\end{array}$ \\
\hline Total land owned & $\begin{array}{r}0.00 \\
(1.28)\end{array}$ & $\begin{array}{r}0.00 \\
(1.15)\end{array}$ & $\begin{array}{r}0.00 \\
(0.97)\end{array}$ & $\begin{array}{r}0.00 \\
(0.39)\end{array}$ & $\begin{array}{r}0.00 \\
(0.38)\end{array}$ & $\begin{array}{r}-0.00 \\
(-0.10)\end{array}$ \\
\hline \multicolumn{7}{|l|}{ Risk Indicator } \\
\hline Number of crops & $\begin{array}{r}-0.02^{* * *} \\
(-6.32)\end{array}$ & $\begin{array}{r}-0.01^{* * *} \\
(-4.63)\end{array}$ & $\begin{array}{r}-0.01^{* * *} \\
(-3.80)\end{array}$ & $\begin{array}{r}-0.01^{* * *} \\
(-8.27)\end{array}$ & $\begin{array}{r}-0.01^{* * *} \\
(-8.37)\end{array}$ & $\begin{array}{r}-0.01^{* * *} \\
(-6.13)\end{array}$ \\
\hline Quality of land & $\begin{array}{r}0.05^{\star \star *} \\
(4.88)\end{array}$ & $\begin{array}{r}0.05^{\star * *} \\
(4.71)\end{array}$ & $\begin{array}{r}0.04^{* * *} \\
(3.92)\end{array}$ & $\begin{array}{r}0.02^{\star \star \star} \\
(4.27)\end{array}$ & $\begin{array}{r}0.02^{\star * \star} \\
(3.95)\end{array}$ & $\begin{array}{r}0.02^{\star \star \star} \\
(4.20)\end{array}$ \\
\hline \multicolumn{7}{|l|}{ Crop Income } \\
\hline Value of meher crops & & $\begin{array}{r}-0.001^{* * *} \\
(-2.92)\end{array}$ & $\begin{array}{r}-0.001^{* * *} \\
(-2.60)\end{array}$ & & $\begin{array}{l}-0.001 \\
(-0.55)\end{array}$ & $\begin{array}{l}-0.001 \\
(-0.83)\end{array}$ \\
\hline Value of belg crops & & $\begin{array}{l}0.001 \\
(0.84)\end{array}$ & $\begin{array}{l}0.001 \\
(1.07)\end{array}$ & & $\begin{array}{l}-0.001 \\
(-1.09)\end{array}$ & $\begin{array}{l}-0.001 \\
(-0.46)\end{array}$ \\
\hline Meher sale dummy & & & $\begin{array}{r}-0.17^{\star \star *} \\
(-7.83)\end{array}$ & & & $\begin{array}{r}-0.11^{* * *} \\
(-9.46)\end{array}$ \\
\hline Belg sale dummy & & & $\begin{array}{l}-0.06^{\star *} \\
(-2.08)\end{array}$ & & & $\begin{array}{r}-0.02 \\
(-1.53)\end{array}$ \\
\hline Constant & $\begin{array}{r}0.01 \\
(0.11)\end{array}$ & $\begin{array}{r}0.02 \\
(0.27)\end{array}$ & $\begin{array}{r}0.06 \\
(0.80)\end{array}$ & $\begin{array}{r}0.16^{* * *} \\
(4.53)\end{array}$ & $\begin{array}{r}0.17^{\star \star *} \\
(4.95)\end{array}$ & $\begin{array}{r}0.20^{* * \star} \\
(5.83)\end{array}$ \\
\hline $\mathrm{N}$ & 2841.00 & 2841.00 & 2841.00 & 2841.00 & 2841.00 & 2841.00 \\
\hline Log-likelihood & -1499.69 & -1495.17 & -1459.60 & & & \\
\hline Chi2 & 466.75 & 472.43 & 509.09 & 445.63 & 443.84 & 562.98 \\
\hline R2_o & & & & 0.12 & 0.12 & 0.16 \\
\hline R2_b & & & & 0.09 & 0.12 & 0.21 \\
\hline $\mathrm{Rho}^{+}$ & 0.14 & 0.12 & 0.08 & 0.08 & 0.04 & 0.07 \\
\hline
\end{tabular}

+The percent contribution of the total variance of the panel-level variance component for panel-Tobit and panel regression. For panel-Tobit estimation marginal effects are reported. Values in brackets are $z$-values. ${ }^{*} p \leq 0.10,{ }^{* *} p \leq 0.05,{ }^{* * *} p \leq 0.01$

In all intensity specifications, risk indicators reveal that if households diversify risk by planting several crops, they engage less in off-farm activities. The other risk indicator is land quality. The result shows that as the quality of land increases, households engage more on off-farm activities. These results are consistent with the effects of risk on the probability of participation in Table 2.

This result is in line with the argument that high quality land demand less labor time and frees up some spare time for farm households to engage in off-farm activities. On the other hand, households who own poor quality land spend more time on own farm than on off-farm activities to guarantee enough food for the family. This is confirmed in both the second stage Heckman estimation and the panel-Tobit estimation. The number of crops planted, which is a proxy for risk diversification mechanism, affect off-farm activities negatively and significantly in all intensity specifications. This is in line with the argument that if households already diversify risk by planting a number of crops, they tend to engage less in off-farm activities compared to those households who planted less number of crops. These results agree with theoretical expectations and previous work on Ethiopia. For instance, Block and Webb (2001) arrived at the same result although they have used different risk indicators. However, Dercon and Krishnan (1996) reported that diversification could not be explained by a household behavior towards risk, contrary to theoretical expectation. 
Almost all crop income variables (except the value of belg crops) affect off-farm intensity negatively and significantly. The key result from crop income (both in value and actual sale) is that farmers with more income from crop activities (especially during the main harvest season) engage less in off-farm activities. An increase in the value of meher crop by one unit decreases off-farm income share by 0.001 units. This, again, confirms that farm and off-farm activities are substitutes, not complements. The same result was alluded to from the negative coefficient of dummy variable for year 1997. Off-farm activities are not a choice for farmers in Ethiopia during the study years. The first priority for farmers is to guarantee enough food production and some cash from the sale of crop production. It is only when there is poor crop harvest that farmers engage in off-farm activities. I argue that the positive coefficient on the belg crops does not contradict these results.

Belg season is the period where only few areas harvest and those who harvest get only small fraction of what they get during meher season. Sites with belg crop income, compared to sites without belg crop income, create off-farm employment opportunities for the idle labor during this slack season of the year. Therefore, the income from belg season production is not enough to cover family needs and on top of that there may be some resources not deployed during this slack season since the farm activities are at low scale. In this situation, we expect to see increased off-farm intensity. In cases when belg crop sale dummy is significant, that is when farmers get more cash income, the positive effect of belg crop disappears (see Table 4), which again confirms that more cash income from crop production leads farmers to stick to farming.

The results support the view that off-farm and on-farm activities compete over limited household resources. It also implies that those households who expect secured agricultural income stay on farm and lower off-farm intensity. Moreover, if farmers sale part of their crops from the belg production, they tend to engage less in off-farm activities. This confirms the widely held view of labor shortage in rural Ethiopia, at least during the main harvest season of a year. The competition of farm and off-farm activities over limited household resources during the main harvest season leads farmers to focus less on off-farm activities during harvest years with favorable weather conditions. This is because staying on farm guarantees food security from own farm production and minimizes the risk of buying food from market when there is possibility of a food price hike.

\section{Conclusions and implications}


The purpose of this study was to examine the determinants of participation in and intensity of off-farm activities in rural Ethiopia during 1994 and 1997 harvest years. The study looked into five key determinants - demographics, seasonality, asset ownership, risk factors, and crop income - as suggested in the literature. The results of the study reveal that in addition to demographic factors, off-farm participation is influenced by asset ownership, seasonal factors, and risk considerations. Although competition from farm activities is not apparent from participation estimation, stronger competition effects emerge from intensity equations. From the demographic factors, one variable that affects intensity is the number of students in a household, which indicates that households with more kids in school tend to engage more in off-farm activities. All other demographic variables have the same effect on intensity and on participation. The year 1997 is the year when farmers engage less in off-farm activities. The expected response to policy reform in 1997 to engage more in off-farm activities was not materialized. It seems rather that farmers' response was to the changes in the underlying weather conditions and farm activities. Even if we assume some positive response to the change in policy in 1997, the reform had the impact of encouraging farm activities more than off-farm activities. Similar result is obtained in the intensity equation.

What is new for the intensity equation is that, as expected, farmers engage more in off-farm activities during the slack months of the survey years. Size of land owned appears to have no effect on intensity as an asset indicator. However, livestock ownership has positive and significant effects on off-farm intensity, similar to the results in participation. Risk indicators also become stronger in the intensity equation. Households who diversify by planting more crops engage less in off-farm activities and households with good quality land spend more time on off-farm activities than those households with poor land quality. One other result that distinguishes participation and intensity equation is the impact of crop income. Incomes from crop production during both seasons seem to have very little effects on the rate of off-farm participation but have strong significant effect on intensity. Stronger result is observed if households sale part of their crops during both seasons. Selling part of crop production provides farmers with the cash that they need to buy tradable goods that they could not produce on their farm. If households secure food from crop production and cash from sale of part of their production, they tend to engage less in off-farm activities.

The implications of the results are clear. Policy makers need to understand the priorities of farm households. Guaranteed food for the family members is the top priority. Farmers also fear price hikes to rely only on income from off-farm to purchase enough food from the market. Their risk perception adds fuel to this fear. One way to convince farmers is to stabilize food market and guarantee access to affordable food supply so that farmers can engage in off-farm activities with 
predictable cost to secure their family's food requirements. Although it costs the government in the short run, the long run potential benefits outweigh the costs by making the structural transformation process a smooth transition. The type of off-farm activities in which farmers engage in should be understood well before designing any policy. From this study, it seems that the types of activities undertaken in the survey sites are low-productive, low-skill types mostly undertaken by resource-poor households. Before encouraging farm households to engage more in off-farm activities, the government must make sure to expand off-farm opportunities with potential for growth. It is also apparent from the results that off-farm activities are seasonal, which peaks not only in slack months but also during bad harvest years (during harvest shortfalls). The government should also expand job opportunities during this months, or years to expand off-farm activities that attract farm households by expanding the provision of the necessary inputs like credit, training and essential tools. It is also important to appreciate the degree of competition between off-farm and farm activities at least during the peak harvest seasons. Government could also tap into the seasonal idle labor during the slack months when farmers tend to engage more in off-farm activities. Government should also invest in infrastructure to create off-farm opportunities in remote parts of the country where most resource poor farmers reside and where market integration is very weak as the village effects show. Given the competition between farm and off-farm activities, the presumption of excess labor in rural sector should be reconsidered in formulating policies.

Finally, it is important to point out some of the caveats of this study as a guide for future research works. First, pastoral parts of the country are not represented in this study. Second, specific labor time allocation of households was not used due to data limitations. Other than village dummies, specific indicators for infrastructure and other communication networks (i.e. road type, access to phone, access to government training facilities) are not used in the analysis. Future research should take into account these factors since the use of these specifics may provided more detailed results for specific regional and national policy design. 


\section{References}

Abdulai, Awudu, and Anna CroleRees. 2001. Determinants of Income Diversification amongst Rural Households in Southern Mali. Food Policy, 26, 4, 437-52.

Barrett, Christopher B., Mesfin Bezuneh, and Abdillahi Aboud. 2001. Income Diversification, Poverty Traps and Policy Shocks in Cote d'Ivoire and Kenya. Food Policy, 26, 4, 367-84.

Barrett, Christopher B., Tom Reardon, and Patrick Webb. 2001a. Nonfarm Income Diversification and Household Livelihood Strategies in Rural Africa: Concepts, Dynamics, and Policy Implications. Food Policy, 26, 4, 315-31.

Berg, Marrit van den, and Girma Earo Kumbi. 2006. Poverty and the rural nonfarm economy in Oromia, Ethiopia. Agricultural Economics, 35, s3, 469-475.

Bevan, Phillipa and Alula Pankhurst. 1996. Ethiopia Village Sociological Survey Reports. Oxford: Centre for the Study of African Economies.

Block, S., and Patrick Webb. 2001. The Dynamics of Livelihood Diversification in Post-famine Ethiopia. Food Policy, 26, 4, 333-50.

Bryceson, Deborah F. 1999. African Rural Labour, Income Diversification and Livelihood Approaches: A Long-Term Development Perspective. Review of African Political Economy, 26, 80, 171-89.

Carswell, Grace. 2002. Livelihood Diversification: Increasing in Importance or Increasingly Recognized? Evidence from Southern Ethiopia. Journal of International Development, 14, 6, 789-804.

de Janvry, Alain. 1994. Farm-Nonfarm Synergies in Africa: Discussion. American Journal of Agricultural Economics, 76, 5, 1183-85.

Deininger, Klaus, and Pedro Olinto. 2001. Rural Nonfarm Employment and Income Diversification in Colombia. World Development, 29, 3, 455-65.

Delgado, Christopher L., and Ammar Siamwalla. 1999. Rural Economy and Farm Income Diversification in Developing Countries. Food security, diversification and resource management: Refocusing the role of agriculture? In the Proceedings of the Twentythird International Conference of Agricultural Economists, Sacramento, California, 126-143.

Dercon, Stefan, and Pramila Krishnan. 1996. Income Portfolios in Rural Ethiopia and Tanzania: Choices and Constraints. Journal of Development Studies, 32, 6, 850-75.

Ellis, Frank. 2000. Rural Livelihoods and Diversity in Developing Countries. New York: Oxford University Press.

1998. Household Strategies and Rural Livelihood Diversification. Journal of Development Studies, 35, 1, 1-38

Escobal, Javier. 2001. The Determinants of Nonfarm Income Diversification in Rural Peru. World Development, 29, 3, 497-508.

Holden, Stein, Bekele Shiferaw, and John Pender. 2004. Non-farm income, household welfare, and sustainable land management in a less-favored area in the Ethiopian Highlands. Food Policy, 29, 369-392.

Kijima, Yoko, Toyoma Mastumoto, and Takashi Yamano. 2006. Nonfarm employment, agriculture, and poverty dynamics: evidence from rural Uganda. Agricultural Economics, 35, s3, 459-467. 
Lanjouw, Peter. 2001. Nonfarm Employment and Poverty in Rural El Salvador. World Development, 29, 3, 529-547.

2000. Rural Non-agricultural Employment and Poverty in Latin America: Evidence from Ecuador and El Salvador. In López, R., and A. Valdés, Rural Poverty in Latin America. Saint Martin's Press: New York, 99-119.

Lanjouw, Jean O., and Peter Lanjouw. 2001. The Rural Non-farm Sector: Issues and Evidence from Developing Countries. Agricultural Economics, 26, 1, 1-23.

Lanjouw, Peter, and Jean O. Lanjouw. 1999. Rural Nonfarm Employment: A Survey. The World Bank, Policy Research Working Paper Series: 1463.

Lanjouw, Peter, Jaime Quizon, and Robert Sparrow. 2001. Non-agricultural Earnings in Periurban Areas of Tanzania: Evidence from Household Survey Data. Food Policy, 26, 4, 385-403.

Lemi, Adugna. 2009. Trade liberalization and change in poverty status in Ethiopia: What are the links? University of Massachusetts Boston, Boston, MA, Working Paper \# 12.

Mastsumoto, Tomoya, Yoko Kijima, and Takashi Yamano. 2006. The role of local nonfarm activities and migration in reducing poverty: evidence from Ethiopia, Kanya, and Uganda. Agricultural Economics, 35, s3, 449-458.

Nawata, Kazumitsu and Nobuko Nagase. 1996. Estimation of sample selection bias models. Econometric Reviews, 15, 4, 387-400.

Reardon, Thomas. 1997. Using Evidence of Household Income Diversification to Inform Study of the Rural Nonfarm Labor Market in Africa. World Development, 25, 5, 735-47.

Reardon, Thomas, Christopher Delgado, and Peter Matlon. 1992. Determinants and Effects of Income Diversification amongst Farm Households in Burkina Faso. Journal of Development Studies, 28, 2, 264-96.

Reardon, Thomas, Eric Crawford, and Valerie Kelly. 1994. Links between Nonfarm Income and Farm Investment in African Households: Adding the Capital Market Perspective. American Journal of Agricultural Economics, 76, 5, 1172-76.

Reardon, Thomas, Julio A. Berdegue, and German Escobar. 2001. Rural Nonfarm Employment and Incomes in Latin America: Overview and Policy Implications. World Development 29, 3, 395-409.

Ruben, Ruerd, and Marrit van den Berg. 2001. Nonfarm Employment and Poverty Alleviation of Rural Farm Households in Honduras. World Development, 29, 3, 549-60.

Sicular, Terry 1986. Using A Farm-Household Model to Analyze Labor Allocation on a Chinese Collective Farm. In Inderjit J. Singh, Lyn Squire and John Strauss (eds.), Agricultural Household Models-Extensions, Applications and Policy. Baltimore: The Johns Hopkins University Press.

Smith D.R., Gordon A., Meadows K., Zwick K. 2001. Livelihood diversification in Uganda: Patterns and determinants of change across two rural districts. Food Policy, 26, 4, 421-435.

Strauss, John. 1986. Appendix: The Theory and Comparative Statics of Agricultural Household Models: A General Approach. In Inderjit J. Singh, Lyn Squire and John Strauss (eds.), Agricultural Household Models-Extensions, Applications and Policy. Baltimore: The Johns Hopkins University Press.

Woldenhanna, T., and Arie Oskam. 2001. Income Diversification and Entry Barriers: Evidence from the Tigray Region of Northern Ethiopia. Food Policy, 26, 4, 351-65. 
Yunez-Naude, Antonio, and J. E. Taylor. 2001. The Determinants of Nonfarm Activities and Incomes of Rural Households in Mexico, with Emphasis on Education. World Development, 29, 3, 561-72. 


\section{ANNEX}

Table A.1: Off-farm Participation Rate by Region and Year

\begin{tabular}{|c|c|c|c|c|c|c|}
\hline \multicolumn{2}{|c|}{$\begin{array}{l}\text { Worked on someone else } \\
\text { land or other employment? }\end{array}$} & \multirow[t]{2}{*}{ Tigray } & \multirow[t]{2}{*}{ Amhara } & \multirow[t]{2}{*}{ Oromia } & \multirow[t]{2}{*}{ SNNP* } & \multirow[t]{2}{*}{ Total } \\
\hline 1994 & & & & & & \\
\hline Yes & $\begin{array}{l}\text { Count } \\
\% \text { of Row } \\
\% \text { within Region }\end{array}$ & $\begin{array}{r}105 \\
20.4 \% \\
70.9 \%\end{array}$ & $\begin{array}{r}120 \\
23.3 \% \\
25.0 \%\end{array}$ & $\begin{array}{r}172 \\
33.4 \% \\
42.6 \%\end{array}$ & $\begin{array}{r}118 \\
22.9 \% \\
26.5 \%\end{array}$ & $\begin{array}{r}515 \\
100.0 \% \\
34.9 \%\end{array}$ \\
\hline & $\%$ of Total & $7.1 \%$ & $8.1 \%$ & $11.6 \%$ & $8.0 \%$ & $34.9 \%$ \\
\hline No & $\begin{array}{l}\text { Count } \\
\% \text { of Row } \\
\% \text { within Region }\end{array}$ & $\begin{array}{r}43 \\
4.5 \% \\
29.1 \%\end{array}$ & $\begin{array}{r}360 \\
37.4 \% \\
75.0 \%\end{array}$ & $\begin{array}{r}232 \\
24.1 \% \\
57.4 \%\end{array}$ & $\begin{array}{r}327 \\
34.0 \% \\
73.5 \%\end{array}$ & $\begin{array}{r}962 \\
100.0 \% \\
65.1 \%\end{array}$ \\
\hline & $\%$ of Total & $2.9 \%$ & $24.4 \%$ & $15.7 \%$ & $22.1 \%$ & $65.1 \%$ \\
\hline Total & $\begin{array}{l}\text { Count } \\
\% \text { of Row } \\
\% \text { of Total }\end{array}$ & $\begin{array}{r}148 \\
10.0 \% \\
10.0 \%\end{array}$ & $\begin{array}{r}480 \\
32.5 \% \\
32.5 \%\end{array}$ & $\begin{array}{r}404 \\
27.4 \% \\
27.4 \%\end{array}$ & $\begin{array}{r}445 \\
30.1 \% \\
30.1 \%\end{array}$ & $\begin{array}{r}1477 \\
100.0 \% \\
100.0 \%\end{array}$ \\
\hline $\begin{array}{l}1997 \\
\text { Yes }\end{array}$ & $\begin{array}{l}\text { Count } \\
\% \text { of Row } \\
\% \text { within Region }\end{array}$ & $\begin{array}{r}28 \\
8.1 \% \\
18.7 \%\end{array}$ & $\begin{array}{r}109 \\
31.7 \% \\
23.3 \%\end{array}$ & $\begin{array}{r}91 \\
26.5 \% \\
22.5 \%\end{array}$ & $\begin{array}{r}116 \\
33.7 \% \\
26.6 \%\end{array}$ & $\begin{array}{r}344 \\
100.0 \% \\
23.6 \%\end{array}$ \\
\hline & $\%$ of Total & $1.9 \%$ & $7.5 \%$ & $6.2 \%$ & $8.0 \%$ & $23.6 \%$ \\
\hline No & $\begin{array}{l}\text { Count } \\
\% \text { of Row } \\
\% \text { within Region }\end{array}$ & $\begin{array}{r}122 \\
11.0 \% \\
81.3 \%\end{array}$ & $\begin{array}{r}359 \\
32.2 \% \\
76.7 \%\end{array}$ & $\begin{array}{r}313 \\
28.1 \% \\
77.5 \%\end{array}$ & $\begin{array}{r}320 \\
28.7 \% \\
73.4 \%\end{array}$ & $\begin{array}{r}1114 \\
100.0 \% \\
76.4 \%\end{array}$ \\
\hline & $\%$ of Total & $8.4 \%$ & $24.6 \%$ & $21.5 \%$ & $21.9 \%$ & $76.4 \%$ \\
\hline Total & $\begin{array}{l}\text { Count } \\
\% \text { of Row } \\
\% \text { of Total }\end{array}$ & $\begin{array}{r}150 \\
10.3 \% \\
10.3 \%\end{array}$ & $\begin{array}{r}468 \\
32.1 \% \\
32.1 \%\end{array}$ & $\begin{array}{r}404 \\
27.7 \% \\
27.7 \%\end{array}$ & $\begin{array}{r}436 \\
29.9 \% \\
29.9 \%\end{array}$ & $\begin{array}{r}1458 \\
100.0 \% \\
100.0 \%\end{array}$ \\
\hline
\end{tabular}

*Southern Nations, Nationalities, and People (SNNP) 
Table A.2: Reasons for Not Participating in Off-farm Activities by Region and Year

\begin{tabular}{|c|c|c|c|c|c|c|}
\hline \multirow{3}{*}{$\begin{array}{l}1994 \\
\text { No employment } \\
\text { opportunities }\end{array}$} & & Tigray & Amhara & Oromia & SNNP* & Total \\
\hline & \multirow{2}{*}{$\begin{array}{l}\text { Count } \\
\% \text { of Row } \\
\% \text { within Region } \\
\% \text { of Total }\end{array}$} & $\begin{array}{r}23 \\
3.2 \% \\
38.3 \%\end{array}$ & $\begin{array}{r}254 \\
35.7 \% \\
53.1 \%\end{array}$ & $\begin{array}{r}225 \\
31.6 \% \\
62.5 \%\end{array}$ & $\begin{array}{r}210 \\
29.5 \% \\
51.2 \%\end{array}$ & $\begin{array}{r}712 \\
100.0 \% \\
54.4 \%\end{array}$ \\
\hline & & $1.8 \%$ & $19.4 \%$ & $17.2 \%$ & $16.1 \%$ & $54.4 \%$ \\
\hline Needed on farm & $\begin{array}{l}\text { Count } \\
\% \text { of Row } \\
\% \text { within Region } \\
\% \text { of Total }\end{array}$ & $\begin{array}{r}6 \\
1.7 \% \\
10.0 \% \\
0.5 \%\end{array}$ & $\begin{array}{r}133 \\
38.4 \% \\
27.8 \% \\
10.2 \%\end{array}$ & $\begin{array}{r}86 \\
24.9 \% \\
23.9 \% \\
6.6 \%\end{array}$ & $\begin{array}{r}121 \\
35.0 \% \\
29.5 \% \\
9.3 \%\end{array}$ & $\begin{array}{r}346 \\
100.0 \% \\
26.5 \% \\
26.5 \%\end{array}$ \\
\hline Job too far away & $\begin{array}{l}\text { Count } \\
\% \text { of Row } \\
\% \text { within Region } \\
\% \text { of Total }\end{array}$ & $\begin{array}{r}1 \\
3.2 \% \\
1.7 \% \\
0.1 \%\end{array}$ & $\begin{array}{r}4 \\
12.9 \% \\
.8 \% \\
0.3 \%\end{array}$ & $\begin{array}{r}7 \\
22.6 \% \\
1.9 \% \\
0.5 \%\end{array}$ & $\begin{array}{r}19 \\
61.3 \% \\
4.6 \% \\
1.5 \%\end{array}$ & $\begin{array}{r}31 \\
100.0 \% \\
2.4 \% \\
2.4 \%\end{array}$ \\
\hline $\begin{array}{l}\text { Wages too low for } \\
\text { kind of job }\end{array}$ & $\begin{array}{l}\text { Count } \\
\% \text { of Row } \\
\% \text { within Region } \\
\% \text { of Total }\end{array}$ & & $\begin{array}{r}9 \\
40.9 \% \\
1.9 \% \\
0.7 \%\end{array}$ & $\begin{array}{r}1 \\
4.5 \% \\
.3 \% \\
0.1 \%\end{array}$ & $\begin{array}{r}12 \\
54.5 \% \\
2.9 \% \\
0.9 \%\end{array}$ & $\begin{array}{r}22 \\
100.0 \% \\
1.7 \% \\
1.7 \%\end{array}$ \\
\hline Taboo & $\begin{array}{l}\text { Count } \\
\% \text { of Row } \\
\% \text { within Region } \\
\% \text { of Total }\end{array}$ & $\begin{array}{r}21 \\
25.0 \% \\
35.0 \% \\
1.6 \%\end{array}$ & $\begin{array}{r}51 \\
60.7 \% \\
10.7 \% \\
3.9 \%\end{array}$ & & $\begin{array}{r}12 \\
14.3 \% \\
2.9 \% \\
0.9 \%\end{array}$ & $\begin{array}{r}84 \\
100.0 \% \\
6.4 \% \\
6.4 \%\end{array}$ \\
\hline Other** & $\begin{array}{l}\text { Count } \\
\% \text { of Row } \\
\% \text { within Region } \\
\% \text { of Total }\end{array}$ & $\begin{array}{r}9 \\
8.0 \% \\
15.0 \% \\
0.7 \%\end{array}$ & $\begin{array}{r}27 \\
23.9 \% \\
5.6 \% \\
2.1 \%\end{array}$ & $\begin{array}{r}41 \\
36.3 \% \\
11.4 \% \\
3.1 \%\end{array}$ & $\begin{array}{r}36 \\
31.9 \% \\
8.8 \% \\
2.8 \%\end{array}$ & $\begin{array}{r}113 \\
100.0 \% \\
8.6 \% \\
8.6 \%\end{array}$ \\
\hline Total & $\begin{array}{l}\text { Count } \\
\% \text { of Total }\end{array}$ & $\begin{array}{r}60 \\
4.6 \%\end{array}$ & $\begin{array}{r}478 \\
36.5 \%\end{array}$ & $\begin{array}{r}360 \\
27.5 \%\end{array}$ & $\begin{array}{r}410 \\
31.3 \%\end{array}$ & $\begin{array}{r}1308 \\
100.0 \%\end{array}$ \\
\hline $\begin{array}{l}1997 \\
\text { No employment } \\
\text { opportunities }\end{array}$ & $\begin{array}{l}\text { Count } \\
\% \text { of Row } \\
\% \text { within Region } \\
\% \text { of Total }\end{array}$ & $\begin{array}{r}18 \\
5.7 \% \\
27.7 \% \\
2 \% \%\end{array}$ & $\begin{array}{r}115 \\
36.5 \% \\
31.0 \% \\
14 \% \%\end{array}$ & $\begin{array}{r}113 \\
35.9 \% \\
60.4 \% \\
14 \%\end{array}$ & $\begin{array}{r}69 \\
21.9 \% \\
37.1 \%\end{array}$ & $\begin{array}{r}315 \\
100.0 \% \\
38.9 \%\end{array}$ \\
\hline Needed on farm & $\begin{array}{l}\text { Count } \\
\% \text { of Row } \\
\% \text { within Region } \\
\% \text { of Total }\end{array}$ & $\begin{array}{r}10 \\
3.1 \% \\
15.4 \% \\
1.2 \%\end{array}$ & $\begin{array}{r}177 \\
54.3 \% \\
47.7 \% \\
21.9 \%\end{array}$ & $\begin{array}{r}59 \\
18.1 \% \\
31.6 \% \\
7.3 \%\end{array}$ & $\begin{array}{r}80 \\
24.5 \% \\
43.0 \% \\
9.9 \%\end{array}$ & $\begin{array}{r}326 \\
100.0 \% \\
40.3 \% \\
40.3 \%\end{array}$ \\
\hline Job too far away & $\begin{array}{l}\text { Count } \\
\% \text { of Row } \\
\% \text { within Region } \\
\% \text { of Total }\end{array}$ & $\begin{array}{r}11 \\
44.0 \% \\
16.9 \% \\
1.4 \%\end{array}$ & $\begin{array}{r}10 \\
40.0 \% \\
2.7 \% \\
1.2 \%\end{array}$ & $\begin{array}{r}2 \\
8.0 \% \\
1.1 \% \\
.2 \%\end{array}$ & $\begin{array}{r}2 \\
8.0 \% \\
1.1 \% \\
.2 \%\end{array}$ & $\begin{array}{r}25 \\
100.0 \% \\
3.1 \% \\
3.1 \%\end{array}$ \\
\hline $\begin{array}{l}\text { Wages too low for } \\
\text { kind of job }\end{array}$ & $\begin{array}{l}\text { Count } \\
\% \text { of Row } \\
\% \text { within Region } \\
\% \text { of Total }\end{array}$ & $\begin{array}{r}2 \\
15.4 \% \\
3.1 \% \\
.2 \%\end{array}$ & $\begin{array}{r}5 \\
38.5 \% \\
1.3 \% \\
.6 \%\end{array}$ & & $\begin{array}{r}6 \\
46.2 \% \\
3.2 \% \\
.7 \%\end{array}$ & $\begin{array}{r}13 \\
100.0 \% \\
1.6 \% \\
1.6 \%\end{array}$ \\
\hline Other** & $\begin{array}{l}\text { Count } \\
\% \text { of Row } \\
\% \text { within Region }\end{array}$ & $\begin{array}{r}24 \\
18.5 \% \\
36.9 \%\end{array}$ & $\begin{array}{r}64 \\
49.2 \% \\
17.3 \%\end{array}$ & $\begin{array}{r}13 \\
10.0 \% \\
7.0 \%\end{array}$ & $\begin{array}{r}29 \\
22.3 \% \\
15.6 \%\end{array}$ & $\begin{array}{r}130 \\
100.0 \% \\
16.1 \%\end{array}$ \\
\hline & $\%$ of Total & $3.0 \%$ & $7.9 \%$ & $1.6 \%$ & $3.6 \%$ & $16.1 \%$ \\
\hline Total & $\begin{array}{l}\text { Count } \\
\% \text { of Total }\end{array}$ & $\begin{array}{r}65 \\
8.0 \%\end{array}$ & $\begin{array}{r}371 \\
45.9 \%\end{array}$ & $\begin{array}{r}187 \\
23.1 \%\end{array}$ & $\begin{array}{r}186 \\
23.0 \%\end{array}$ & $\begin{array}{r}809 \\
100.0 \%\end{array}$ \\
\hline
\end{tabular}

age, child care (nursing) and others.

Table A.3: Descriptive Statistics of the variables used in estimation by year 
Adugna Lemi: Determinants of income diversification...

\begin{tabular}{lcccc}
\hline & $\mathbf{N}$ & Mean & $\mathbf{N}$ & Mean \\
\hline Age of household head (years) & 1476 & 46.42 & 1469 & 44.88 \\
Female headed dummy & 1476 & 0.23 & 1469 & 0.23 \\
Dependency ratio & 1476 & 0.34 & 1425 & 0.39 \\
Adult equivalent & 1476 & 4.77 & 1469 & 5.58 \\
Value of agricultural tools (in birr) & 1476 & 30.91 & 1469 & 36.89 \\
Area of total land owned (in hectare) & 1476 & 1.95 & 1469 & 1.64 \\
Ratio of area of land rented in & 1346 & 0.09 & 1281 & 0.064 \\
Value of livestock (in birr) & 1476 & 960.35 & 1469 & 1033.51 \\
Value of meher crops (in birr) & 1476 & 1113.20 & 1469 & 2926.62 \\
Value of belg crops (in birr) & 1476 & 281.50 & 1469 & 456.65 \\
Dummy for meher sale & 1317 & 0.46 & 1317 & 0.64 \\
Dummy for belg sale & 1317 & 0.20 & 1317 & 0.21 \\
Quality of land & 1476 & 1.38 & 1469 & 0.92 \\
Number of crops harvested & 1476 & 5.21 & 1469 & 6.02 \\
\hline
\end{tabular}


Ethiopian Journal of Economics, Volume XVIII, No 1, April 2009

\begin{tabular}{|c|c|c|c|c|c|c|c|c|}
\hline \multirow[b]{2}{*}{$\begin{array}{c}\text { Regio } \\
\mathrm{n}\end{array}$} & \multirow[b]{2}{*}{ Survey site } & \multirow[b]{2}{*}{ Location } & \multirow[b]{2}{*}{ Main Harvest } & \multicolumn{5}{|c|}{ Survey Round : Time of Interview } \\
\hline & & & & 1989 & $\begin{array}{c}\text { Round1 } \\
1994\end{array}$ & $\begin{array}{l}\text { Round 2 } \\
1994-95\end{array}$ & $\begin{array}{c}\text { Round 3 } \\
1995\end{array}$ & $\begin{array}{c}\text { Round } 4 \\
1997\end{array}$ \\
\hline 1 & Haresaw & Tigray & October-November & & June-July & January & March & June \\
\hline 1 & Geblen & Tigray & October-November & & June-July & January & March & June \\
\hline 3 & Dinki & N. Shoa & December & March April & March-April & November & January & October, November \\
\hline 3 & Debre Berhan & N.Shoa & November-December & March-April & March-April & October & March & June - August \\
\hline 3 & Yetmen & Gojjam & November-December & & March-April & October & March & September, October \\
\hline 3 & Shumsha & S.Wollo & October-December & & June-July & December-January & May & October, November \\
\hline 4 & Sirbana Godeti & Shoa & November-December & & March-April & November & March & June, July \\
\hline 4 & Adele Keke & Hararghe & November-December & $\begin{array}{l}\text { November- } \\
\text { December }\end{array}$ & May-June & October & April & October, November \\
\hline 4 & Koro-degaga & Arssi & October-November & November- & May-June & November-December & May- June & June, July \\
\hline $\begin{array}{l}4 \\
7\end{array}$ & $\begin{array}{l}\text { Turfe Kechemane } \\
\text { Imdibir }\end{array}$ & $\begin{array}{l}\text { S.Shoa } \\
\text { Shoa (Gurage) }\end{array}$ & $\begin{array}{l}\text { December } \\
\text { October-December }\end{array}$ & & $\begin{array}{l}\text { March-April } \\
\text { March-April }\end{array}$ & $\begin{array}{l}\text { September-October } \\
\text { October }\end{array}$ & $\begin{array}{l}\text { March- April } \\
\text { March }\end{array}$ & $\begin{array}{l}\text { September, October } \\
\text { June, July }\end{array}$ \\
\hline 7 & Aze Deboa & $\begin{array}{l}\text { Shoa } \\
\text { (Kembata) }\end{array}$ & October-November & & March-April & September-October & March & September, October \\
\hline 8 & Addado & Sidamo (Dilla) & December-January & & March-April & January & March & June, July \\
\hline 9 & Gara Godo & Sidamo & August-December & March & March-May & October & March & June, July \\
\hline 9 & Doma & Gama Gofa & September-December & May-June & April-May & December-January & May-June & November \\
\hline
\end{tabular}

